\title{
Fanconi Anemia Group C Protein
}

National Cancer Institute

\section{Source}

National Cancer Institute. Fanconi Anemia Group C Protein. NCI Thesaurus. Code C85885.

Fanconi anemia group C protein ( $558 \mathrm{aa}, \sim 63 \mathrm{kDa}$ ) is encoded by the human FANCC gene.

This protein may be involved in DNA cross-link repair and cell cycle checkpoint regulation. 